\title{
Adjunctive treatment of chronic idiopathic urticaria and angioedema with sulfasalazine
}

\author{
T Pitt ${ }^{*}, \mathrm{R}$ Warrington, C Kalicinsky \\ From Canadian Society of Allergy and Clinical Immunology Annual Scientific Meeting 2009 \\ Halifax, Canada. 22-25 October 2009
}

\section{Rationale}

Urticaria is a common condition that affects as many as $25 \%$ of people at some time in their lives. Chronic recurrent urticaria and angioedema can be frustrating and often refractory to conventional treatment. The purpose of this study was to evaluate the efficacy of Sulfasalazine in the treatment of unremitting recurrent urticaria and angioedema.

\section{Methods}

We performed a retrospective chart review of 20 patients with chronic idiopathic urticaria/angioedema (CIU) treated with Sulfasalazine as adjunctive therapy at the Winnipeg Health Science Centre from 2005-2009. We recorded demographic data, response to Sulfasalazine, presence of the IgE receptor antibody, and side effects.

\section{Results}

20 patients were treated with Sulfasalazine as adjunctive therapy and 1 patient was lost to follow up. The patient's ages ranged between 27-75 years with a mean of 48 years and $10(50 \%)$ were female. IgE receptor antibody status was determined in 12 patients and 6 patients were positive. Out of the 19 patients who are still being followed, $10(52.6 \%)$ failed to respond to the Sulfasalazine, and 9 (47.4\%) responded to Sulfasalazine with 2 partial responders and 7 complete responders. Side effects noted included: increased liver function tests, leucopenia, dyspepsia, flatulence nausea, pyrosis and a rash.

\section{Conclusions}

Sulfasalazine may be a useful adjunctive treatment for patients with CIU. Larger blinded, placebo controlled trials are required to confirm its efficacy.

\footnotetext{
Health Sciences Centre, Winnipeg, MB, Canada
}

Published: 12 May 2010

doi:10.1186/1710-1492-6-S1-P25

Cite this article as: Pitt et al:: Adjunctive treatment of chronic idiopathic urticaria and angioedema with sulfasalazine. Allergy, Asthma \& Clinical Immunology 2010 6(Suppl 1):P25.
Submit your next manuscript to BioMed Central and take full advantage of:

- Convenient online submission

- Thorough peer review

- No space constraints or color figure charges

- Immediate publication on acceptance

- Inclusion in PubMed, CAS, Scopus and Google Scholar

- Research which is freely available for redistribution

Submit your manuscript at www.biomedcentral.com/submit
C Biomed Central 